\title{
Electrokinetic dewatering of mine tailings from hydrometallurgical processes
}

\author{
JQ Shang The University of Western Ontario, Canada \\ Y Xu The University of Western Ontario, Canada
}

\begin{abstract}
Fine-grained tailings (leach residue and gypsum) resulting from hydrometallurgical processes (acid leach followed by lime neutralisation) of nickel laterite ores are proving difficult to dewater using conventional dewatering methods (thickeners/vacuum filters). To generate a dense non-segregating slurry or paste that can be deposited on surface in the form of a stable stack, more innovative dewatering methods are required. The current work involves working on thickened nickel laterite tailings to produce a paste product for surface disposal. Achieving greater dewatering would offer advantages compared to conventional slurry deposition such as reducing the size of impoundments; reducing the size and costs of containment dams; and decreasing water sent to the impoundment. It also offers environmental advantages, including reduced leachate generation and decreased permeability of paste (homogeneous mass). Electrokinetic (EK) consolidation is a soil improvement technique that has been mostly used for soft fine-grained soils, such as silts and clays. The treatment involves applying a direct current across electrodes embedded into the soil. The current induces the movement of soil-water from the anode (positive pole) toward the cathode (negative pole). Dewatering and consolidation are achieved when the water is permitted to drain at the cathode and prohibited to enter the anode. The electrochemical reactions are associated with the EK process, which leads to a pH gradient in soil, generation of hydrogen and oxygen gases at electrodes and corrosion of consumable anodes, which must be addressed on a project-specific basis. The objective of this research is to study the viability of using EK to dewater tailings (leach residue and gypsum) from hydrometallurgical processes. The electroosmotic (EO) flow rate and coefficient of EO permeability $\left(k_{e}\right)$ are measured to assess the effectiveness of EK dewatering. The study includes comprehensive material characterisation and EK cell tests. The results of the study indicate:
\end{abstract}

1. EO generated significant water flow in the tailings sample. The tailings have stable electrical conductivity, i.e. the applied current can be maintained relatively constant over time under a constant voltage. The $k_{e}$ values are in the range of $1.00 \times 10^{-9}$ to $7.00 \times 10^{-9} \mathrm{~m}^{2} / \mathrm{V} / \mathrm{sec}$, which is considered very favourable for EO dewatering.

2. The electric conductivities of the saturated tailings are in the range of $2,000-2,300 \mu \mathrm{S} / \mathrm{cm}$, and the tailings porewater has the electric conductivity of $8,000 \mu \mathrm{S} / \mathrm{cm}$, which is considered favourable in terms of power consumption for EK dewatering.

3. The zeta potentials of the tailings before and after EO tests are stable in the $\mathrm{pH}$ range of 4-9, indicating EO dewatering would be effective in tailings without pre-treatment.

Keywords: mine tailings, electrokinetics, electroosmosis, dewatering, hydrometallurgical process

\section{Introduction}

In mining operations, large quantities of tailings are generated daily from ore processing, in which a significant portion has grain sizes less than $10 \mu \mathrm{m}$, often referred to as ultrafine tailings (UFT). The tailings are discharged through pipe lines to tailings ponds, in which coarse particles settle quickly, whereas UFT may remain suspended as slurry for years. The slow settling of tailings is challenging to the management of containment facilities well beyond the mine closure and imposes environmental impacts. Currently, dewatering of UFT is mainly relying on self-weight consolidation. Existing dewatering technologies, such as 
chemical additives, vacuum filtration and preloading consolidation, have shown limited success in large scale field applications, hence active research in the mining community is carried out to accelerate tailings dewatering and to increase water recycling.

Electrokinetics (EK) has been applied on dewatering and consolidation of geo-materials, such as contaminated river sediment and soft clays. EK treatment has been successfully applied and shown promising potentials in dewatering of fine tailings in previous research and field applications (e.g. Lockhart 1986; Shang 1997a, 1997b; Sprute \& Kelsh 1975, 1980; Stanczyc \& Feld 1964; Guo \& Shang 2013; Shang et al. 2012; Shang \& Mohamedelhassan 2001). The feasibility of EK treatment, however, is highly material specific, i.e. the effectiveness of treatment is dependent of the material physical, chemical and mineralogical characteristics (Shang 2011). The objective of this research is to quantitatively assess the viability of using EK to dewater tailings (leach residue and gypsum) from hydrometallurgical processes.

The electroosmotic (EO) flow rate in a geomaterial is related to the coefficient of EO permeability $\left(k_{e}\right)$ and the applied electric field intensity (voltage gradient), i.e.

$$
k_{e}=\frac{Q}{E}
$$

where:

$$
\begin{aligned}
& \mathrm{Q}=\text { the average flow rate }\left(\mathrm{m}^{3} / \mathrm{m}^{2} / \mathrm{sec}\right) . \\
& \mathrm{E} \quad=\text { the applied electric field intensity (voltage gradient, } \mathrm{V} / \mathrm{m} \text { ). }
\end{aligned}
$$

The electroosmotic permeability $k_{e}$ is an important parameter in the viability assessment of EK dewatering and should be measured prior to an EK dewatering application. It has been established in geotechnical applications that $\mathrm{EO}$ consolidation is effective in a specific range of soil parameters (Table 1).

Table 1 Design parameters in EO consolidation (Rittirong \& Shang 2015)

\begin{tabular}{lll}
\hline Parameter & Unit & Typical range \\
\hline$k_{\mathrm{h}}$, hydraulic conductivity & $\mathrm{m} / \mathrm{sec}$ & $10^{-10}-10^{-8}$ \\
$k_{\text {e }}$, electroosmotic permeability & $\mathrm{m}^{2} / \mathrm{V} / \mathrm{sec}$ & $\sim 10^{-9}$ \\
$\kappa$, electrical conductivity of soil & $\mathrm{S} / \mathrm{m}$ & $0.01-0.5$ \\
E, electric field intensity & $\mathrm{V} / \mathrm{m}$ & $20-100$ \\
$C_{\mathrm{V}}$, coefficient of consolidation & $\mathrm{m}^{2} / \mathrm{sec}$ & $10^{-8}-10^{-7}$ \\
$P$, hourly power consumption & $\mathrm{kWh} / \mathrm{m}^{3}$ & $0.01-1$ \\
\hline
\end{tabular}

In this research, the EO flow rate and coefficient of $k_{e}$ are measured under various DC current (electric field intensity) to assess the effectiveness of EK dewatering.

\section{$2 \quad$ Material characterisations}

The tailings investigated in this study consist of mainly leach residue and gypsum, which were generated from hydrometallurgical processes of nickel ores (nickel laterite acid leach followed by lime neutralisation). The tailings have more than $80 \%$ particles with sizes in the range of 1-10 $\mu \mathrm{m}$. The average specific gravity of tailings solids is 2.64. The material characterisation of the testing tailings is provided in Table 2.

The zeta potential of the tailings was measured by a zeta potential analyser (Brookhaven Instruments Corporation). The sample was prepared by mixing the original tailings solids and distilled water in a glass beaker and shaking on a horizontal shaker for more than 10 minutes until the tailings completely blended in the solution. Ten measurements were carried out and the average zeta potential value was $-23.20 \mathrm{mV}$. The $\mathrm{pH}$ values before and after zeta potential analysis were 7.68 and 7.55 respectively. Since the zeta potential 
of tailings solids is directly related to the suspension chemistry, it will not be affected by adding distilled water in the measurement. The original water $\mathrm{pH}$ value was 7.0 and the electric conductivity was $8,210 \mu \mathrm{s} / \mathrm{cm}$.

Table 2 Material characterisation of tailings tested

\begin{tabular}{lcl}
\hline Parameter & Unit & Typical value \\
\hline Mineralogy from XRD* analysis & & \\
Gypsum & $\mathrm{w} / \mathrm{w} \%$ & 63 \\
Jarosite & $\mathrm{w} / \mathrm{w} \%$ & 36 \\
Quartz & $\mathrm{w} / \mathrm{w} \%$ & 1 \\
Major elements from ICP-MS** analysis & \\
$\mathrm{Fe}$ & $\mathrm{mg} / \mathrm{g}$ & 130 \\
$\mathrm{Ca}$ & $\mathrm{mg} / \mathrm{g}$ & 80 \\
$\mathrm{Al}$ & $\mathrm{mg} / \mathrm{g}$ & 8.4 \\
$\mathrm{Mg}$ & $\mathrm{mg} / \mathrm{g}$ & 7.4 \\
$\mathrm{Ni}$ & $\mathrm{mg} / \mathrm{g}$ & 1.9 \\
$\mathrm{Cr}$ & $\mathrm{mg} / \mathrm{g}$ & 1.8 \\
$\mathrm{Ti}$ & $\mathrm{mg} / \mathrm{g}$ & 1.6 \\
\hline *XRD: $\mathrm{X}-\mathrm{R}$ diffraction. \\
$* *$ ICP-MS: Inductively coupled plasma-mass spectrometry.
\end{tabular}

\section{$3 \quad$ Electroosmotic cell test and results}

The EO cell test setup is shown in Figure 1. The apparatus consists of an EO cell, loading plate, electrodes and DC power supply. The EO cell contains three main components; an anode reservoir, a specimen compartment, and a cathode reservoir. The cell is made of Plexiglas with dimensions $35 \times 10 \times 25 \mathrm{~cm}$ (length $x$ width $\times$ height). A woven wire cloth stainless steel mesh with $1.6 \mathrm{~mm}$ wire diameter and $30 \%$ open area was used as the cathode. An expanded titanium mesh (1.6 mm thickness, 30\% open area) coated with titanium dioxide and iridium oxide $\left(\mathrm{TiO}_{2} / \mathrm{IrO}_{x}\right)$, i.e. dimensionally stable anode (DSA), was used as the anode. Both anode and cathode have the same dimensions of $9.7 \times 30 \mathrm{~cm}$ (width $\times$ height), wrapped by a geosynthetic filter to prevent tailings solids enter the reservoirs.

The DC power supply was connected to the electrodes directly. The water levels in the anode and cathode reservoirs were equalised by adjusting the water levels of the recharge and discharge tubes. The voltage during the test was monitored using voltage probes installed at the electrode interface. A loading plate was placed on the top of the soil specimen in the cell, through which a designated surcharge pressure was applied via a loading frame and dead loads. The tailings were carefully placed in the EO cell without any pre-treatment. The tailings specimen was $18 \times 20 \times 10 \mathrm{~cm}$ (length $\times$ height $\times$ width). A high-density polyethylene geomembrane was placed on the top of the tailings specimen to ensure one-dimensional (horizontal) flow between two electrodes. The surcharge pressure applied on the tailings specimen was between 0 and $15 \mathrm{kPa}$. The tailings specimen was consolidated for 24 hours, at which time the specimen settlement virtually stopped. The soil-water content was measured after consolidation and before the EO test started. The testing conditions and tailings properties are summarised in Table 3. 


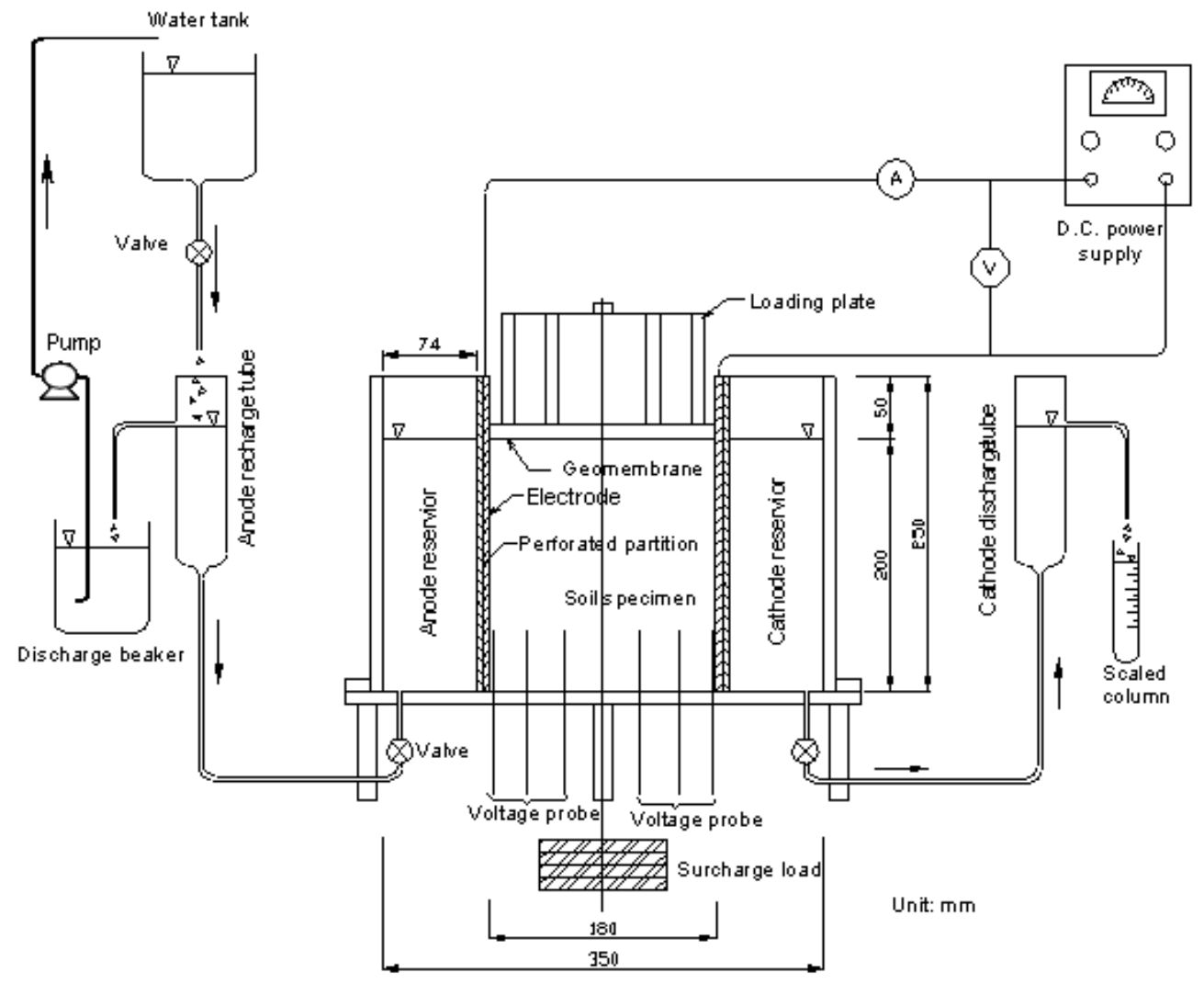

Figure 1 Electroosmotic cell setup

Table 3 The testing conditions and tailings properties

\begin{tabular}{|c|c|c|}
\hline Parameter & Unit & Amount or description \\
\hline Tailings bulk unit weight & $\mathrm{kN} / \mathrm{m}^{3}$ & 15.0 \\
\hline Tailings water content & $w / w \%$ & 80 \\
\hline Tailings hydraulic conductivity & $\mathrm{m} / \mathrm{sec}$ & $7 \times 10^{-8}$ \\
\hline Surcharge pressure before EK test & $\mathrm{kPa}$ & $0-15$ \\
\hline Degree of saturation & $\%$ & 100 \\
\hline Drainage & & Left and right reservoir (2-way) \\
\hline Tailings sample size & $\mathrm{cm}$ & 20 (height) $\times 18$ (length) $\times 10$ (width) \\
\hline Applied voltage & V & $8.0-21.3$ \\
\hline Applied current & $\mathrm{mA}$ & $150-500$ \\
\hline Electrodes & & Cathode: SS316 mesh; Anode: DSA $\left(\mathrm{TiO}_{2} / \mathrm{IrO}_{x}\right)$ mesh \\
\hline Hydraulic gradient & & 0 \\
\hline \multicolumn{3}{|c|}{ Parameters measured during an EO test: } \\
\hline \multicolumn{3}{|c|}{$\begin{array}{l}\text { EO flow (water discharge), voltage at locations across the EO cell, DC current, water } \mathrm{pH} \text { and electrical } \\
\text { conductivity, surface settlement at the anode and cathode sides of the EO cell, hydraulic conductivity }\left(\mathrm{k}_{\mathrm{h}}\right) \\
\text { by seepage tests in EO cell. }\end{array}$} \\
\hline
\end{tabular}


Figure 2 shows the applied electric field intensity $(\mathrm{V} / \mathrm{m})$ over time. In the first 10 days, tailings went through self-weight consolidation without power application; from days 11 to 17 , a DC voltage was applied to generate an electric field intensity $50 \mathrm{~V} / \mathrm{m}$; and from days 18 to 25 , the DC voltage was increased to reach the electric field intensity $100 \mathrm{~V} / \mathrm{m}$. The electric conductivities of tailings samples were calculated from the applied DC voltage and current in real time, which were in the range of 2,067-2,300 $\mu \mathrm{S} / \mathrm{cm}$.

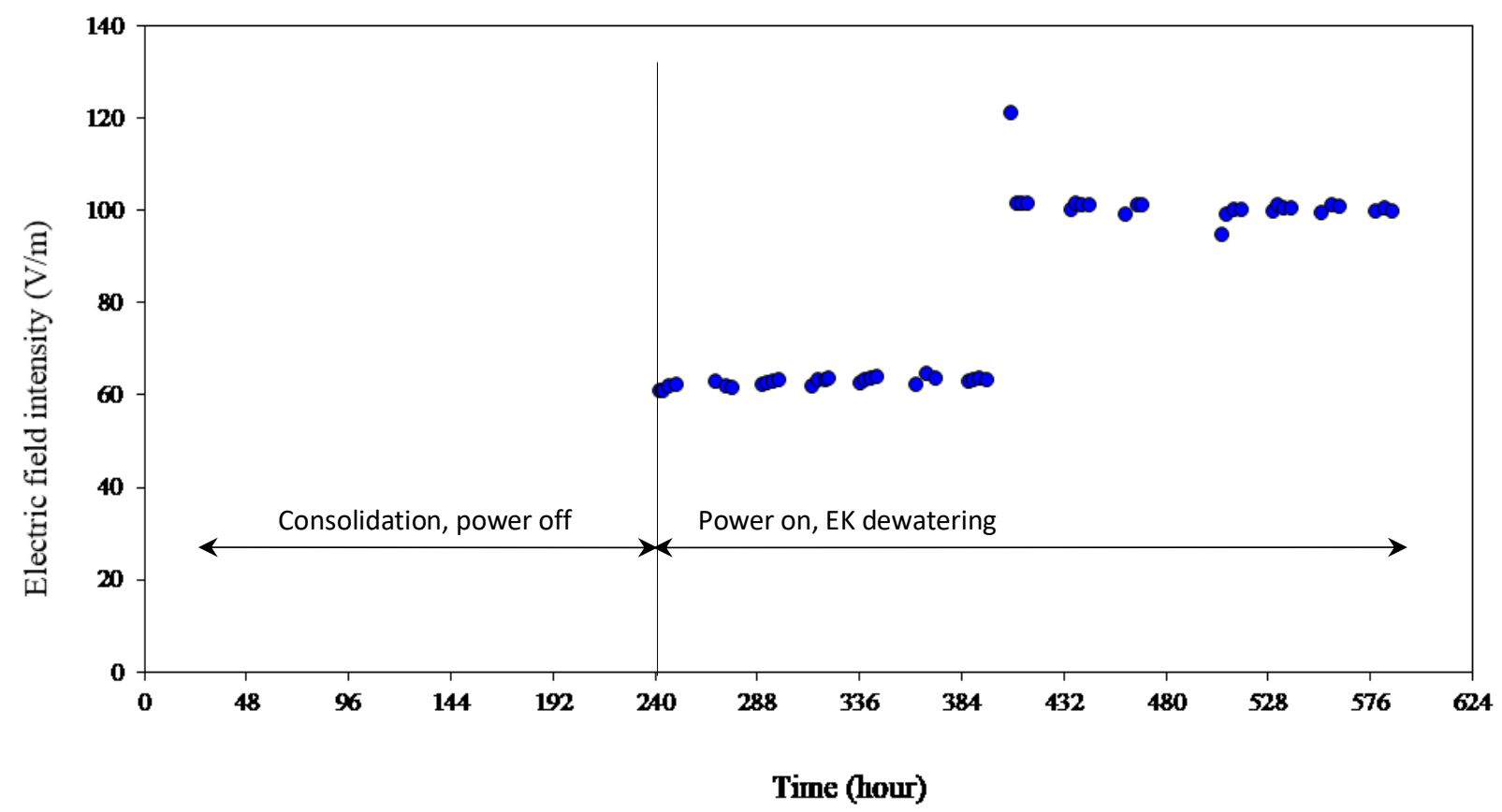

Figure 2 Applied voltage gradient during EO cell test

Figure 3 shows the water collected during the EO test versus real time. As shown in the figure, there was no water collection in the consolidation process in the first 240 hours with power off and the water flow started immediately after the voltage application.

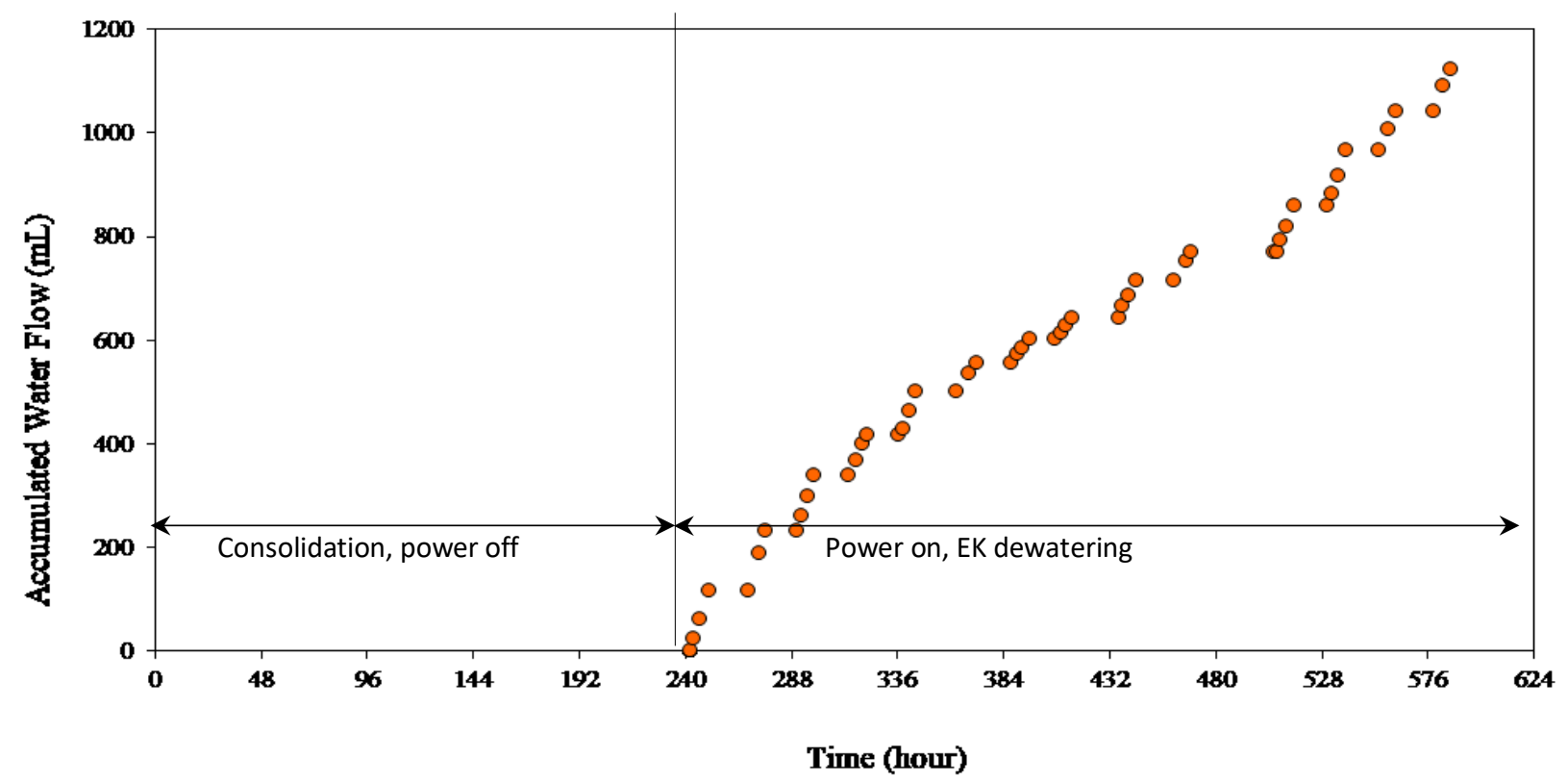

Figure 3 Accumulated water flow during EO cell test 
Figure 4 shows the EO-induced water flow rate versus time. The flow rate was calculated by the water collected per hour in the testing period, which was in the range of 5-15 mL/hr. After 17 days of EO test, an increase in the applied voltage gradient (from 50-100 V/m, see Figure 2) did not further enhance the EO flow rate.

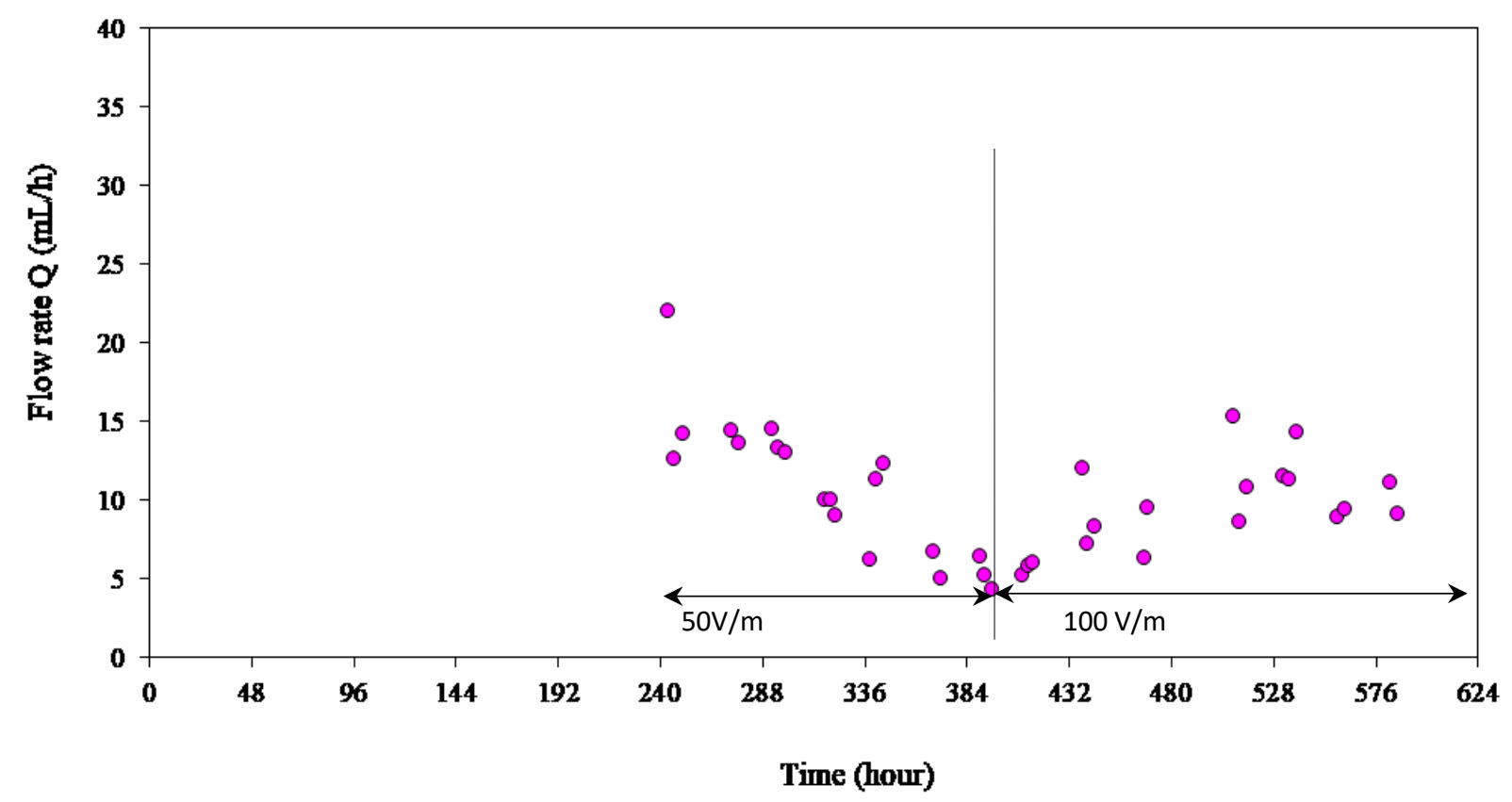

Figure 4 The EO flow rate as a function of testing time

Figure 5 shows the electroosmotic permeability, $k_{e}\left(\mathrm{~m}^{2} / \mathrm{V} / \mathrm{sec}\right.$, calculated from the flow rate (Figure 4$)$ and applied voltage gradient (Figure 2), based on Equation 1.

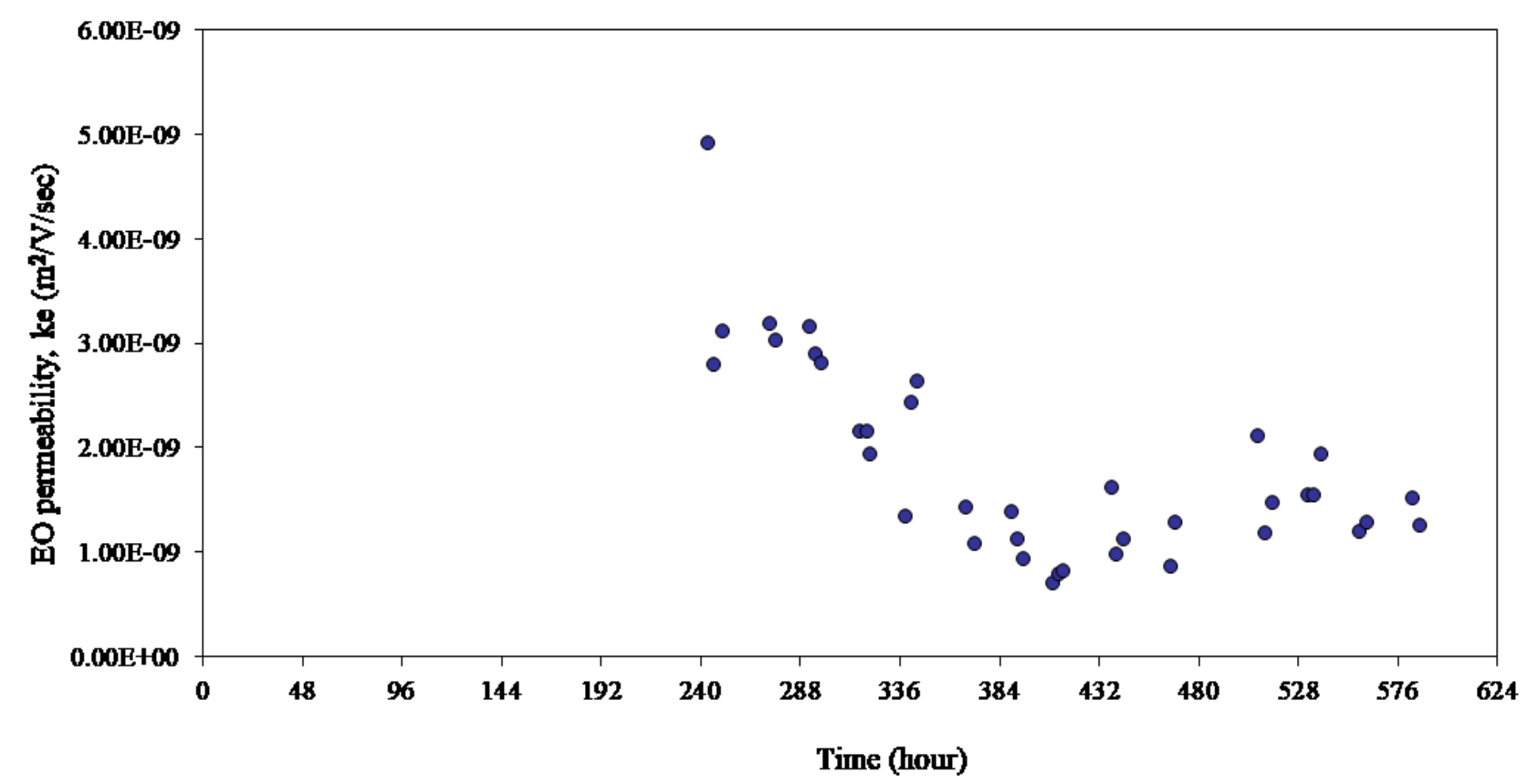

Figure 5 The coefficient of EO permeability $\left(k_{e}\right)$ as a function of testing time

As shown in Figure 5, the magnitude of $k_{e}$ for the tailings in the first two days of EO operation (from 240 to $288 \mathrm{hrs}$ ) was $3.10 \times 10^{-9} \mathrm{~m}^{2} / \mathrm{V} / \mathrm{sec}$ on average; then dropped to $1.30 \times 10^{-9} \mathrm{~m}^{2} / \mathrm{V} / \mathrm{sec}$ during the second two days of EO operation (from 288 to $336 \mathrm{hrs}$ ). After four days of testing, $k_{e}$ was stable with an average magnitude of $1.30 \times 10^{-9} \mathrm{~m}^{2} / \mathrm{V} / \mathrm{sec}$. The water flow by electroosmosis is proportional to $k_{e}$ under a constant 
applied voltage gradient. The decrease of $k_{e}$ with treatment time indicates the reduction of dewatering rate (Equation 1). Referring to Figure 2, an increase of the electric field intensity after seven days of EO treatment did not enhance the EO flow rate (Figure 4) and the $k_{e}$ value (Figure 5), indicating that the selection of the electric field intensity is important for optimisation of EO dewatering operation. Compared to Table 1, the $k_{e}$ values of the tailings samples tested in this study are consistent in magnitude with fine-grained soils.

Figure 6 shows the tailings settlement during the EO cell test. Most settlement was induced by the surcharge pressure. The significant settlement between $144 \mathrm{hr}$ and $192 \mathrm{hr}$ was generated by the seepage test for the hydraulic conductivity $\left(k_{h}\right)$ measurement. Differential settlements during the EO tests at current $300 \mathrm{~mA}$ and higher after 192 hours were observed at the anode side of the tailings sample.

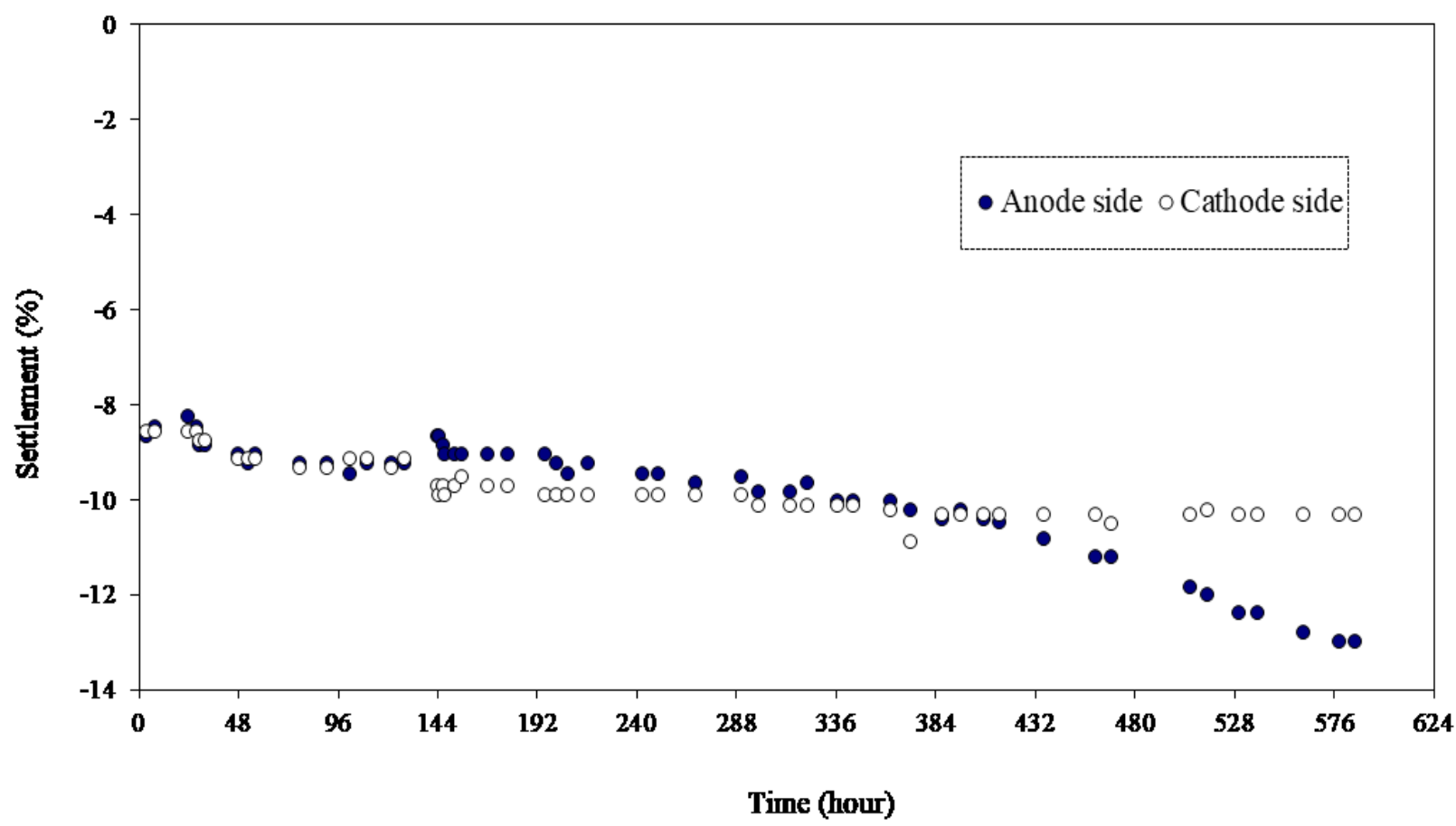

Figure 6 The tailings settlement during an electroosmotic (EO) cell test

The results of chemical analyses after EO cell test are summarised in Table 4. The element analyses indicate that dissolved cations, especially $\mathrm{Cr}, \mathrm{Cu}, \mathrm{Fe}, \mathrm{Ni}$ and $\mathrm{Zn}$ presented in higher concentrations at the anode side than that at the cathode side, obviously due to differences in water $\mathrm{pH}$. It is noted that $\mathrm{SO}_{4}{ }^{2-}$ and $\mathrm{Cl}^{-}$are dominant anions in the tailings. Because the anode used was dimensionally stable, the ionic species measured represent changes are solely attributed to chemical equilibria in tailings solids and water.

\section{Discussion}

As shown in Figure 5, the magnitude of $k_{e}$ for the tailings in the first two days of EO operation (from 240 to $288 \mathrm{hrs}$ ) was $3.10 \times 10^{-9} \mathrm{~m}^{2} / \mathrm{V} / \mathrm{sec}$ on average; then dropped to $1.30 \times 10^{-9} \mathrm{~m}^{2} / \mathrm{V} / \mathrm{sec}$ during the second two days of EO operation (from 288 to $336 \mathrm{hrs}$ ). After four days of testing, $k_{e}$ was stable with an average magnitude of $1.30 \times 10^{-9} \mathrm{~m}^{2} / \mathrm{V} / \mathrm{sec}$. Referring to Figure 2, an increase of the electric field intensity after seven days of EO treatment did not enhance the EO flow rate (Figure 4) and the $k_{e}$ value (Figure 5), indicating that the selection of the electric field intensity is important for optimisation of EO dewatering operation.

The typical $k_{e}$ values in soils, such as clay or silty clay, are in the order of $10^{-9} \mathrm{~m}^{2} / \mathrm{V} / \mathrm{sec}$, see Table 1 (Rittirong \& Shang 2015). When the $k_{h}$ of a geotechnical material is low, the EO flow is significant compared to the hydraulic flow, and the higher $k_{e}$ values represents higher EO flow rate (Stancyzc \& Feld 1964; Sprute \& Kelsh 1975, 1980; Lockhart 1986; Shang 1997a, 1997b). The magnitude of $k_{e}$ measured in this study was $3 \times 10^{-9} \mathrm{~m}^{2} / \mathrm{V} / \mathrm{sec}$, indicating that the mine tailings is suitable for EO dewatering operation. 
Table 4 Results of chemical analysis after EO cell tests

\begin{tabular}{|c|c|c|c|c|c|c|c|}
\hline \multirow[t]{2}{*}{ Element } & \multirow[t]{2}{*}{ Unit } & \multirow{2}{*}{$\begin{array}{l}\text { Original } \\
\text { Water }\end{array}$} & \multicolumn{5}{|c|}{ After EO test } \\
\hline & & & $\begin{array}{l}\text { Water } \\
\text { Anode } \\
\text { reservoir }\end{array}$ & $\begin{array}{l}\text { Water } \\
\text { Cathode } \\
\text { reservoir }\end{array}$ & $\begin{array}{l}\text { Porewater } \\
\text { Anode side } \\
\text { of tailings }\end{array}$ & $\begin{array}{l}\text { Porewater } \\
\text { Centre of } \\
\text { tailings }\end{array}$ & $\begin{array}{l}\text { Porewater } \\
\text { Cathode side } \\
\text { of tailings }\end{array}$ \\
\hline As & $\mathrm{mg} / \mathrm{L}$ & 0.04 & 0.02 & 0.01 & 2.41 & 0.06 & 0.03 \\
\hline $\mathrm{Cd}$ & $\mathrm{mg} / \mathrm{L}$ & 0.01 & 0.00 & 0.00 & 2.01 & 0.00 & 0.00 \\
\hline Co & $\mathrm{mg} / \mathrm{L}$ & 0.05 & 0.02 & 0.01 & 3.31 & 0.99 & 0.03 \\
\hline $\mathrm{Cr}$ & $\mathrm{mg} / \mathrm{L}$ & 1.48 & 1.46 & 0.46 & 117 & 0.15 & 0.06 \\
\hline $\mathrm{Cu}$ & $\mathrm{mg} / \mathrm{L}$ & 32.6 & 0.82 & 0.06 & 12.27 & 0.08 & 0.13 \\
\hline $\mathrm{Fe}$ & $\mathrm{mg} / \mathrm{L}$ & 19.7 & 0.90 & 0.10 & 478 & 3.92 & 1.53 \\
\hline $\mathrm{Mg}$ & $\mathrm{mg} / \mathrm{L}$ & 120 & 116 & 83.5 & 92.21 & 128 & 112 \\
\hline $\mathrm{Mn}$ & $\mathrm{mg} / \mathrm{L}$ & 0.67 & 0.13 & 0.00 & 22.39 & 44.2 & 0.79 \\
\hline Mo & $\mathrm{mg} / \mathrm{L}$ & 0.02 & 0.01 & 0.20 & 0.09 & 0.29 & 0.09 \\
\hline $\mathrm{Nb}$ & $\mathrm{mg} / \mathrm{L}$ & 0.00 & 0.00 & 0.00 & 0.07 & 0.01 & 0.00 \\
\hline $\mathrm{Ni}$ & $\mathrm{mg} / \mathrm{L}$ & 2.33 & 0.89 & 0.05 & 82.7 & 41.63 & 1.29 \\
\hline$P$ & $\mathrm{mg} / \mathrm{L}$ & 0.27 & 0.16 & 0.13 & 2.74 & 0.13 & 0.09 \\
\hline $\mathrm{Sb}$ & $\mathrm{mg} / \mathrm{L}$ & 0.04 & 0.01 & 0.01 & 2.39 & 1.08 & 0.02 \\
\hline V & $\mathrm{mg} / \mathrm{L}$ & 0.01 & 0.01 & 0.01 & 4.07 & 0.01 & 0.00 \\
\hline w & $\mathrm{mg} / \mathrm{L}$ & 0.03 & 0.03 & 0.02 & 0.72 & 0.01 & 0.04 \\
\hline $\mathrm{Zn}$ & $\mathrm{mg} / \mathrm{L}$ & 4.54 & 1.01 & 0.01 & 8.77 & 0.10 & 0.04 \\
\hline $\mathrm{Zr}$ & $\mathrm{mg} / \mathrm{L}$ & 0.00 & 0.01 & 0.01 & 0.19 & 0.01 & 0.00 \\
\hline $\mathrm{pH}$ & & 7.0 & 2.0 & 12.0 & 4.0 & 7.6 & 10.0 \\
\hline $\begin{array}{l}\text { Zeta } \\
\text { potential }\end{array}$ & $\mathrm{mV}$ & $\begin{array}{l}-23.2 \\
\text { (original } \\
\text { tailings) }\end{array}$ & $n / a$ & $\mathrm{n} / \mathrm{a}$ & $\begin{array}{l}-16.0 \\
\text { (tailings on } \\
\text { anode side) }\end{array}$ & $\begin{array}{l}-22.0 \text { (tailings } \\
\text { in between } \\
\text { anode and } \\
\text { cathode) }\end{array}$ & $\begin{array}{l}\text {-17.0 (tailings } \\
\text { on cathode } \\
\text { side) }\end{array}$ \\
\hline
\end{tabular}

\section{Conclusion}

To assess the viability of EK dewatering of tailings from hydrometallurgical processes, a laboratory study was carried out. The EO flow rate and coefficient of EO permeability $\left(k_{e}\right)$ are measured in EK cell tests, along with a comprehensive material characterisation. The results of the study indicate:

1. The EO tests under voltage gradients from $50-100 \mathrm{~V} / \mathrm{m}$ generated significant water flow in the tailings sample. The $k_{e}$ values are in the range of $1.00 \times 10^{-9}$ to $7.00 \times 10^{-9} \mathrm{~m}^{2} / \mathrm{V} / \mathrm{sec}$, which are considered favourable for EK dewatering.

2. The tailings have stable electrical conductivity, which are in the range of $2,000-2,300 \mu \mathrm{S} / \mathrm{cm}$, and the tailings porewater has the electric conductivity of $8,000 \mu \mathrm{S} / \mathrm{cm}$. This is considered favourable for EO dewatering in terms of power consumption.

3. The zeta potentials of the tailings before and after EO tests are stable in the $\mathrm{pH}$ range of 4-9, indicating EO dewatering would be effective for in situ treatment of tailings under the natural water $\mathrm{pH}$. 


\section{Acknowledgement}

This research is sponsored by Golder Paste Technology Ltd. and the Natural Science and Engineering Research Council of Canada.

\section{References}

Guo, Y \& Shang, JQ 2013, 'A study on electrokinetic dewatering of oil sands tailings', Environmental Geotechnics, vol. 1, issue 2, pp. 121-134.

Lockhart, NC 1986, 'Electro-dewatering of fine suspensions', in CSIRO Division of Fossil Fuels (ed.), Advances in Solid-Liquid Separation, pp. 241-274.

Rittirong, A \& Shang, J Q 2015, 'Electro-osmotic stabilization', in B Indraratna, J Chu and C Rujikiatkamjorn (eds), Ground Improvement - Case Histories, Butterworth-Heinemann, Oxford.

Shang, JQ, Elazar, R \& Goldt, R 2012, 'Electrokinetic (EK) dewatering of Orr Dam sediment', Proceedings of the 24th International Offshore and Polar Engineering Conference, pp. 17-22.

Shang, JQ 2011, 'Electrokinetics: engineering applications and recent development', Advances in Unsaturated Soil, Geo-Hazard, and Geo-Environmental Engineering Geotechnical Special Publications, no. 217, pp. 1-8.

Shang, JQ 1997a, 'Electrokinetic sedimentation: a theoretical and experimental study', Canadian Geotechnical Journal, vol. 34, no. 2, pp. 305-314.

Shang, JQ 1997b, 'Electrokinetic dewatering of clay slurries as engineering soil covers', Canadian Geotechnical Journal, vol. 34, no. 1, pp. 78-86.

Shang, JQ \& Mohamedelhassan, E 2001, 'Electrokinetic dewatering of Eneabba West mine tailings: An experimental study.' Proceedings of the Soft Ground Technology Conference, no. 112, pp, 346-350.

Sprute, RH \& Kelsh, DJ 1975, 'Electrokinetic densification of hydraulic backfil I- a field test', Report of Investigations 8075, United States Bureau of Mines.

Sprute, RH \& Kelsh, DJ 1980, 'Dewatering fine particle suspensions with direct current', in P Somasundaran (ed.), Proceedings of the International Symposium on Fine Particles Processing, Society of Mining Engineers of American Institute of Mining, Metallurgical and Petroleum Engineers, Nevada, pp. 1828-1844.

Stanczyc, MH \& Feld, IL 1964, 'Electro-dewatering tests of Florida phosphate rock slime', Report of Investigations 6451, United States Bureau of Mines. 
